\title{
Lack of Conserved miRNA Deregulation in HPV-Induced Squamous Cell Carcinomas
}

\author{
Jaroslav Nunvar ${ }^{1,2, *}$, Lucie Pagacova ${ }^{1,2}$, Zuzana Vojtechova ${ }^{1,2}$, Nayara Trevisan Doimo de Azevedo ${ }^{3}$, \\ Jana Smahelova ${ }^{1,2}$, Martina Salakova ${ }^{1,2}\left(\mathbb{D}\right.$ and Ruth Tachezy ${ }^{1,2}$ \\ 1 Department of Genetics and Microbiology, Faculty of Science, Charles University, \\ 12844 Prague, Czech Republic; Lucka.pagacova@seznam.cz (L.P.); zuzana.vojtechova@natur.cuni.cz (Z.V.); \\ jana.smahelova@natur.cuni.cz (J.S.); martina.salakova@natur.cuni.cz (M.S.); ruth.tachezy@natur.cuni.cz (R.T.) \\ 2 BIOCEV-Biotechnology and Biomedicine Centre of the Academy of Sciences and Charles University, \\ 25250 Vestec, Czech Republic \\ 3 Genomics Core Facility, EMBL, 69117 Heidelberg, Germany; nayara.azevedo@embl.de \\ * Correspondence: jaroslav.nunvar@natur.cuni.cz
}

check for updates

Citation: Nunvar, J.; Pagacova, L.; Vojtechova, Z.; Azevedo, N.T.D.d.; Smahelova, J.; Salakova, M.; Tachezy, R. Lack of Conserved miRNA Deregulation in HPV-Induced Squamous Cell Carcinomas. Biomolecules 2021, 11, 764. https:// doi.org/10.3390/biom11050764

Academic Editor: Vladimir N. Uversky

Received: 13 April 2021

Accepted: 15 May 2021

Published: 20 May 2021

Publisher's Note: MDPI stays neutral with regard to jurisdictional claims in published maps and institutional affiliations.

Copyright: (C) 2021 by the authors Licensee MDPI, Basel, Switzerland. This article is an open access article distributed under the terms and conditions of the Creative Commons Attribution (CC BY) license (https:/ / creativecommons.org/licenses/by/ $4.0 /)$.

\begin{abstract}
Squamous cell carcinomas (SCCs) in the anogenital and head and neck regions are associated with high-risk types of human papillomaviruses (HR-HPV). Deregulation of miRNA expression is an important contributor to carcinogenesis. This study aimed to pinpoint commonly and uniquely deregulated miRNAs in cervical, anal, vulvar, and tonsillar tumors of viral or non-viral etiology, searching for a common set of deregulated miRNAs linked to HPV-induced carcinogenesis. RNA was extracted from tumors and nonmalignant tissues from the same locations. The miRNA expression level was determined by next-generation sequencing. Differential expression of miRNAs was calculated, and the patterns of miRNA deregulation were compared between tumors. The total of deregulated miRNAs varied between tumors of different locations by two orders of magnitude, ranging from 1 to 282 . The deregulated miRNA pool was largely tumor-specific. In tumors of the same location, a low proportion of miRNAs were exclusively deregulated and no deregulated miRNA was shared by all four types of HPV-positive tumors. The most significant overlap of deregulated miRNAs was found between tumors which differed in location and HPV status (HPV-positive cervical tumors vs. HPV-negative vulvar tumors). Our results imply that HPV infection does not elicit a conserved miRNA deregulation in SCCs.
\end{abstract}

Keywords: squamous cell carcinoma; human papillomavirus; microRNA

\section{Introduction}

Human papillomaviruses (HPV), species-specific viruses infecting mucosal and cutaneous epithelium of the host, can cause benign diseases such as papillomata or warts; however, some HPV types have oncogenic potential and are reported to be responsible for up to $5 \%$ of all tumors worldwide and up to $30 \%$ of those whose development is attributed to infectious agents [1]. The most common carcinoma associated with HPV infection is cervical cancer, which is caused by HPV in almost $100 \%$ of cases. HPV is also associated with other tumors of the anogenital region such as vaginal tumors, where HPV participates in $78 \%$ of cases, vulvar tumors with $25 \%$ of HPV-positive cases, anal tumors with almost $90 \%$ of HPV-positive cases, and penile tumors with $50 \%$ of HPV-positive cases [2]. The second region where HPVs play the etiological role in cancer development is head and neck, especially the oropharyngeal location [3]. The proportion of HPV-associated oropharyngeal cancers is increasing around the world, reaching $40-80 \%$ of cases in the USA and $20-90 \%$ of cases throughout Europe [4-6].

The proper molecular profiling of HPV-positive and HPV-negative tumors and comparisons of differences between the two etiologies is necessary for expanding our understanding of the mechanisms of carcinogenesis. There are only few publications addressing 
the differences in molecular profiles between HPV-associated and HPV-independent tumors. Koncar et al. determined the expression of 24 proteins by immunohistochemistry, mutations of 48 genes by sequencing, and copy number alterations for six genes by in situ hybridization for cohorts of vulvar, anal, cervical, and oropharyngeal tumors, reporting the HPV-positive tumors to have similar molecular profiles [7]. However, the HPV positivity in their samples was determined based on the p53 status, which is not an established surrogate marker for the detection of HPV. Nevertheless, Tuna and Amos compared The Cancer Genome Atlas (TCGA) database data from studies analyzing HPV-driven tumors; they found similar genomic alterations in HPV-negative and HPV-positive cases but also detected distinct epigenomic and transcriptomic profiles between these groups [8]. Genomic comparison of HPV-positive and HPV-negative oral squamous cell carcinomas (SCCs) was performed by Gillison et al. and they specified a number of unique genetic features for virus-associated tumors [9]. Similarly, significant genetic differences between HPV-positive and HPV-negative tumors were revealed in several other studies $[10,11]$. So far, only two studies using whole-exome sequencing of vulvar tumors with regard to HPV positivity have been published $[12,13]$. They have shown that genetic alterations in vulvar carcinomas encompass mutations and copy number alterations that differ between HPV-positive and HPV-negative cases, in addition to common alterations observed irrespective of the HPV status.

Promising specific, sensitive, and clinically significant biomarkers are miRNAs, small single-stranded non-coding RNAs that regulate gene expression and play an important role in cell development, growth, and differentiation. Their expression has been reported to be deregulated in tumors. MicroRNAs play a role in stimulating tumor growth by negative regulation of tumor suppressor genes or by positive regulation of oncogenes. Specific miRNA profiles have been reported in many studies of various tumors, for example, of leukemia, breast cancer, lung cancer, or prostate cancer [14-18]. Numerous studies focused on the analysis of miRNA profiles in cervical cancer [19-22]; however, miRNA expression in tumors of the rest of anogenital regions is less researched, with only two studies analyzing miRNA profiles in vulvar cancer [23,24]. MicroRNA expression in head and neck cancers has been increasingly studied, and several studies on cell lines or tumors have been published [25-29]; however, they did not examine their association with HPV status. HPV status was addressed in two studies of Lajer et al. $[19,30]$ who defined the group of core HPV miRNAs specific for two types of HPV-positive tumors, cervical and head and neck. Furthermore, Miller et al. analyzed miRNA expression in HPV-positive and HPV-negative oropharyngeal carcinomas and validated the data against The Cancer Genome Atlas, identifying HPV-associated oncogenic miRNAs [31]. In our previous study, we focused on miRNA profiles in HPV-negative and HPV-positive tonsillar tumors and in cervical tumors and on the comparison with a model system of keratinocyte clones [32] and defined the core HPV miRNAs, but they did not overlap with those from the study by Lajer et al. The lack of comparability between the outcomes of these studies can be most likely attributed to the anatomical heterogeneity of the analyzed head and neck tumors and to the different methodological approaches.

In our study, we analyzed the miRNA expression profiles in a set of anogenital tumors associated with HPV, namely, cervical, vulvar, and anal tumors, and in a set of tonsillar tumors by next-generation sequencing (NGS) in an attempt to identify commonly deregulated miRNAs exclusive for HPV-dependent SCCs. To our knowledge, this is the first study to analyze miRNA profiles in four HPV-driven types of tumors which employs a unified methodological approach. Furthermore, this study provides miRNA expression analysis of insufficiently researched anal and vulvar carcinomas.

\section{Materials and Methods}

\subsection{Clinical Samples}

Samples of SCCs were obtained from the Department of Pathology and Molecular Medicine, 2nd Faculty of Medicine, Charles University and Motol University Hospital, 
Prague, and from the Institute of Pathology, 3rd Faculty of Medicine, Charles University and University Hospital Kralovske Vinohrady, Prague. All tissue samples originated from unique patients. Formalin-fixed paraffin-embedded (FFPE) samples prepared from tumor tissues were stained and macrodissected [32]. The HPV status of FFPE samples was determined by P16 immunochemistry and HPV DNA detection [33]. All HPV-positive tumors contained high-risk HPV16. For each anatomical location (tonsillar, cervical, vulvar, anal), the sample set consisted of three HPV-positive tumors, three HPV-negative tumors, and three samples of normal tissue. Cervical HPV-negative tumors were not included due to their unavailability.

\subsection{Sample Processing for NGS}

Total RNA was isolated from macrodissected sections of FFPE samples using AllPrep ${ }^{\circledR}$ DNA/RNA FFPE (Qiagen, Germantown, MD, USA). RNA concentration and quality

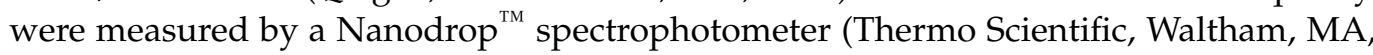
USA) and Experion chip electrophoresis (Bio-Rad, Hercules, CA, USA). From purified RNA, sequencing libraries were prepared using the TruSeq Small RNA Library prep kit (Illumina, San Diego, CA, USA). The libraries were sequenced on NextSeq 500 (Illumina, San Diego, CA, USA) at the Division of Molecular Medicine, Ruđer Bošković Institute (Zagreb, Croatia), or the EMBL's Genomics Core Facility (GeneCore) (Heidelberg, Germany) using the NextSeq 500/550 High Output Kit (Illumina, San Diego, CA, USA). Sequencing reads were deposited in the SRA, GenBank (BioProject ID: PRJNA718204).

\subsection{Analysis of NGS Data}

Sequencing reads were trimmed off adapter sequences using the FastQ toolkit Basespace App (Illumina). The trimmed reads were mapped onto human reference genome assembly GRCh38.p13 using the Geneious mapper [34] (max. mismatches: 10\%, max. gaps: $10 \%)$. The complete analysis of DE between replicate tumor samples and normal tissues (expression normalization, DE calculation, calculation of statistical significance) was carried out using the DESeq2 package [35]. The miRNAs exhibiting fold change of expression $(\mathrm{FC}) \geq 2.0$ and statistical support of $p$ adj ( $p$-value adjusted for multiple testing) $\leq 0.1$ were extracted and further analyzed. The Adonis-Bray test [36] with 10,000 permutations was used to test the association of global miRNA expression with the sample metadata categories (tissue type, anatomic location, HPV status).

\section{Results and Discussion}

\subsection{Global Characterization of miRNA Expression}

Since deregulation of the cellular miRNA network is commonly observed in carcinogenesis, we aimed to characterize the patterns of miRNA expression in a set of tissue samples encompassing tumors from different anatomical locations and differing in HPV status. Samples of HPV-associated tumors (anogenital and tonsillar tumor tissues), of the corresponding HPV-negative tumors (if available), and of healthy tissues were collected from three patients per sample type and processed for NGS. Sequencing yields ranged from 338,068 to $4,273,955$ total reads per sample; the percentage of miRNA-derived reads varied from $6.3 \%$ to $82.9 \%$ (Table S1). The expression level values were calculated for individual miRNAs as their proportion among the total miRNA reads (Table S2).

The similarity of tissue samples based on their miRNA expression profiles is visualized in Figure 1 by principal component analysis (PCA) and a heatmap. In both plots, the clustering and thus the similarity of samples correlated with their anatomical locations. Tonsillar samples formed a separated cluster. Among the anogenital samples, anal samples clustered separately from genital samples. A notable separation was detected between the genital (i.e., cervical and vulvar) samples. All cervical tumors, all vulvar HPV-negative tumors, and one vulvar HPV-positive tumor were distinct from normal cervical and vulvar tissues and two vulvar HPV-positive tumors; the extent of dissimilarity of their miRNA expression profiles was readily discernable in both PCA and the heatmap (Figure 1). The 
Adonis-Bray test revealed that the miRNA expression was most significantly associated with anatomical location (anal/cervical/vulvar/tonsillar; $p=0.0001$ ) and tissue type (tumor/nonmalignant; $p=0.001$ ) of samples. This is in accordance with miRNA expression being long recognized to exhibit tissue-specific and tumor-specific differences [37-40]. The association with HPV status (positive/negative) was weaker and not significant $(p=0.074)$.

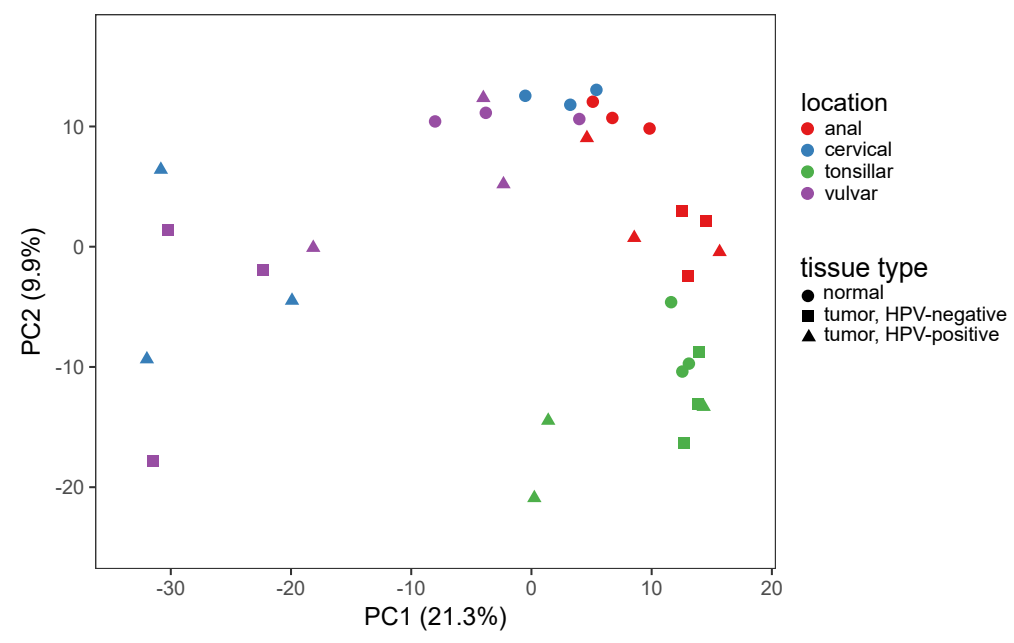

(a)

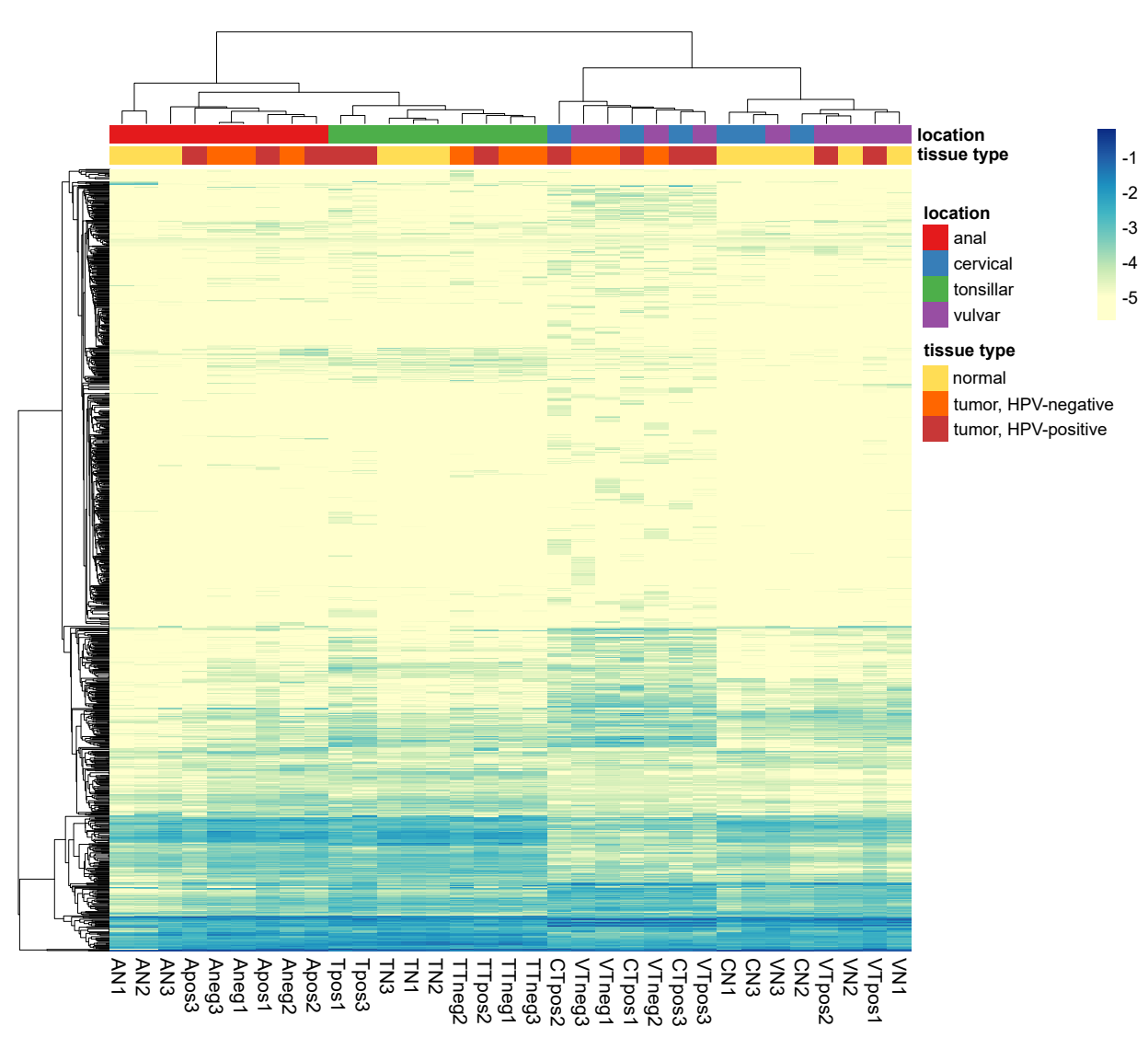

(b)

Figure 1. Clustering of tissue samples by miRNA expression profiles. (a) PCA plot; (b) heatmap plot. The heatmap color scale depicts log-transformed abundance values of individual miRNAs among total miRNA sequencing reads. Visualizations were carried out in ClustVis [41]. 


\subsection{Differential Expression of miRNA in SCCs}

We compared miRNA expression between tumor and normal tissues of the same locations, identifying miRNAs which exhibited differential expression (DE). This type of comparison is particularly suitable for pointing out the miRNAs whose deregulation is linked with carcinogenesis. Figure 2a shows the total numbers of deregulated miRNAs in the seven tumor types differing in anatomical location and HPV status. The total numbers of deregulated miRNAs varied greatly among tumor types. Cervical HPV-positive tumors exhibited the highest number of deregulated miRNAs, followed by vulvar HPV-negative tumors. This is in accordance with the marked separation of the miRNA expression profiles of these tumor samples from all other tissues as seen in Figure 1. On the opposite end of the spectrum of miRNA deregulation, HPV-positive vulvar tumors yielded only a single downregulated miRNA (see below). Again, this was mirrored in the clustering of miRNA expression profiles; $2 / 3$ of vulvar HPV-positive tumor samples were intermingled between normal vulvar tissues (Figure 1 ).

The cross-tumor comparison revealed that the largest proportion of deregulated miRNAs was specific to a single tumor type (149/239 and 94/210 upregulated and downregulated miRNAs, respectively; Figure $2 b$ ). The numbers of miRNAs which exhibited shared deregulation decreased with the increasing extent of common deregulation among the seven tumor types. Both upregulated and downregulated miRNAs followed this pattern (Figure 2b). Downregulated miRNAs were more abundant than upregulated miRNAs among the most widely deregulated miRNAs. Specifically, 58 vs. 68,28 vs. 28,4 vs. 14 , and 0 vs. 6 miRNAs (upregulated vs. downregulated) exhibited shared deregulation in two, three, four, and five tumor types, respectively (Figure 2b). No miRNA was deregulated in more than five tumor types. The miRNAs whose deregulation was detected in most tumor types of the set are likely to play a conserved role in tumorigenesis. A literature search confirmed that all six miRNAs downregulated in 5/7 tumor types were determined to function as tumor suppressors in SCCs (Table 1). Notably, the sole miRNA downregulated in HPV-positive vulvar cancers (MIR451A) was present among these most widely deregulated miRNAs.

Table 1. The most commonly deregulated miRNAs which exhibited downregulation in 5/7 studied tumor types. All the listed miRNAs were demonstrated to act as tumor suppressor miRNA in SCCs, based on their experimentally confirmed characteristics relevant to carcinogenesis (invasiveness, proliferation).

\begin{tabular}{|c|c|c|c|c|}
\hline Gene & miRNA & $\begin{array}{c}\text { Downregulated in } \\
\text { (Location/HPV Status) }^{1}\end{array}$ & Targets in SCCs & References \\
\hline hsa-miR-101-3p & MIR101-1 & $\begin{array}{l}\text { anal } /-, \text { cervical } /+, \text { tonsillar } /-, \\
\text { tonsillar } /+, \text { vulvar } /-\end{array}$ & $\begin{array}{l}\text { CDK8, COX-2, CXCR7, EZH2, FOS, } \\
\text { JAK2, MALAT1, TGFBR1, ZEB1 }\end{array}$ & [42-52] \\
\hline hsa-miR-10b-5p & MIR10B & $\begin{array}{l}\text { anal } /-, \text { cervical } /+, \text { tonsillar } /-, \\
\text { tonsillar } /+, \text { vulvar } /-\end{array}$ & HOXA1, IGF1R, TIAM1 & [53-55] \\
\hline hsa-miR-29c-3p & MIR29C & $\begin{array}{l}\text { anal } /-, \text { cervical } /+ \text {, tonsillar } /-, \\
\text { tonsillar } /+, \text { vulvar } /-\end{array}$ & CCNE, ITGA6, LAMC2 & {$[56,57]$} \\
\hline hsa-miR-30a-5p & MIR30A & $\begin{array}{l}\text { anal } /-, \text { cervical } /+, \text { tonsillar } /-, \\
\text { tonsillar/ }+ \text {, vulvar } /-\end{array}$ & FOXD1, FZD2, MEF2D, WNT2 & [58-60] \\
\hline hsa-miR-451a & MIR451A & $\begin{array}{l}\text { cervical/+, tonsillar/-, } \\
\text { tonsillar/+, vulvar/ }- \text {, vulvar/+ }\end{array}$ & $\begin{array}{l}\text { CDKN2D, ESDN, KIF2A, } \\
\text { MAP3K1, PDPK1 }\end{array}$ & [61-64] \\
\hline hsa-miR-195-5p & MIR195 & $\begin{array}{l}\text { anal } /+, \text { cervical } /+, \text { tonsillar } /- \\
\text { tonsillar } /+, \text { vulvar } /-\end{array}$ & $\begin{array}{l}\text { ARL2, BCL2, CCND1, CCND2, CDC42, } \\
\text { DCUN1D1, HDGF, MYB, ROCK1, } \\
\text { SMAD3, SMAD7, TRIM14, VEGF, YAP1 }\end{array}$ & [65-78] \\
\hline
\end{tabular}

\footnotetext{
${ }^{1} \mathrm{FC} \geq 2.0, \operatorname{padj} \leq 0.1$.
} 


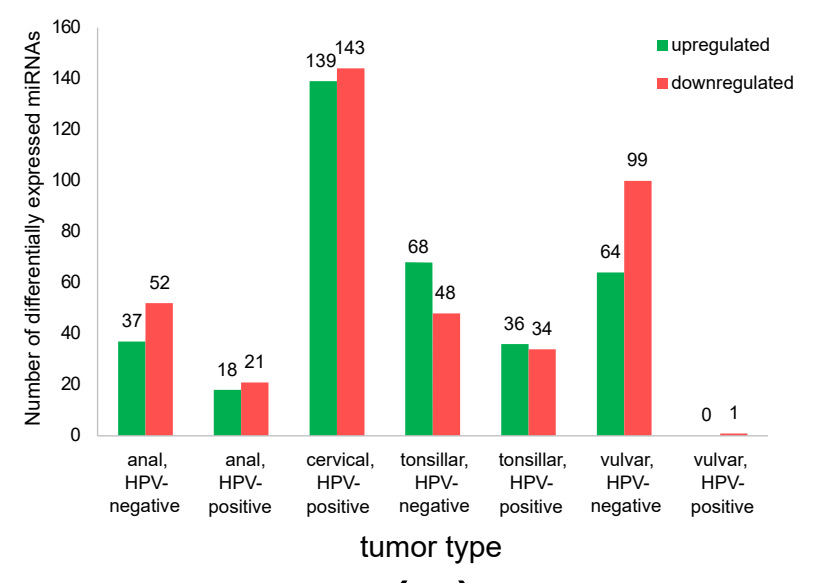

(a)

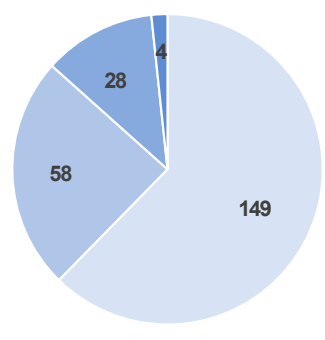

upregulated miRNAs
Sum of all individual miRNAs deregulated in

$=1=2 \approx 3=4-5$

out of 7 tumor types

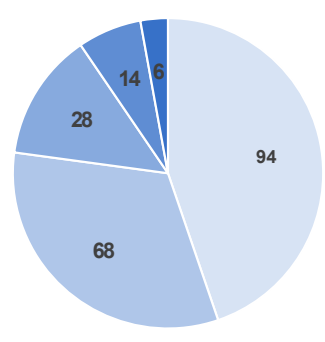

downregulated miRNAs

(b)

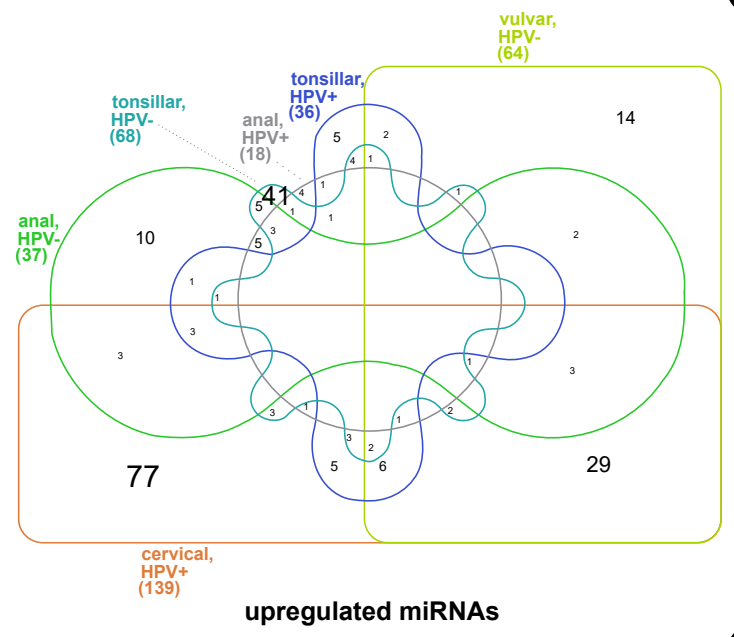

(c)

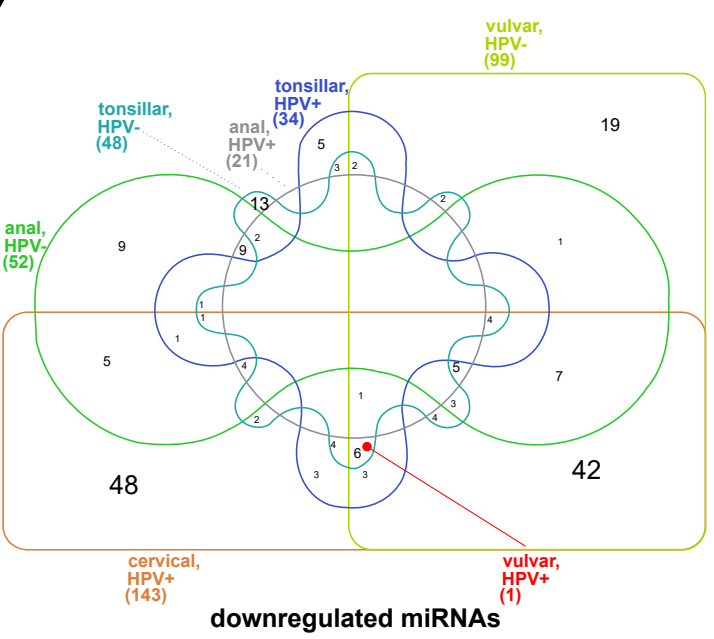

$151020 \quad 40 \quad 60$ miRNAs

Figure 2. DE of miRNAs in tumors of different locations and HPV status. (a) Total numbers of differentially expressed miRNAs in each of the seven analyzed tumor types. (b) The miRNAs that exhibited shared deregulation across the seven studied tumor types. The values denote the total numbers of miRNAs which were deregulated specifically in one tumor type and those whose deregulation was common to two, three, four, or five tumor types. No miRNAs were deregulated in more than five tumor types. (c) Venn diagrams depicting the numbers of unique and shared differentially expressed miRNAs among the seven studied tumor types. The font size range is denoted in the legend. Zero values were omitted. The placement of the sole miRNA deregulated in HPV-positive vulvar tumors (MIR451A) is marked with a red dot. DE values were calculated with respect to normal tissues and filtered (FC $\geq 2.0$, padj $\leq 0.1$; see Materials and Methods). For DE values of individual miRNAs, see Table S3. Venn diagrams were created using InteractiVenn [79].

\subsection{Limited Role of HPV in miRNA Deregulation}

Since infection with high-risk HPV16 is a key factor which delineates tumors between and within different anatomical locations, we investigated whether infection with HPV is 
functionally translated into a common set of deregulated miRNAs. Core HPV miRNAs were focused on in two previous studies [19,32]; however, both analyses were limited to two groups of HPV-positive tumors (cervical and head and neck SCCs). Figure 2c shows that the miRNAs which exhibited deregulation only in HPV-positive tumors were present in minute numbers. Specifically, a single miRNA (miR-146a-5p) was upregulated exclusively in HPV-positive anal and cervical tumors, and a single miRNA (miR-210-3p) was upregulated exclusively in HPV-positive anal and tonsillar tumors. Both miRNAs have been previously shown to be involved in tumorigenesis. The deregulation of miR-146a$5 p$ was observed in many types of cancers (reviewed in [80]), including cervical tumors where it functions as oncomiR, stimulating proliferation of cells [81]. MiR-210-3p was characterized as a hypoxia-regulated miRNA involved in many biological processes and was shown to be overexpressed in many tumors including head and neck cancer [82]. Five miRNAs (miR-663a, miR-769-5p, miR-1307-5p, miR-3196, miR-4800-3p) were upregulated and three miRNAs (miR-139-5p, miR-142-5p, miR-574-3p) were downregulated exclusively in HPV-positive tonsillar and cervical tumors. Downregulation of miR-139-5p and miR574-3p in HPV-positive tonsillar and cervical tumors is in agreement with the results reported by Lajer et al. [19]. The deregulation of both miRNAs was observed in many other cancer types; the role of miR-139-5p as a tumor suppressor was confirmed in cervical tumors and head and neck tumors $[83,84]$; however, the function of miR-574-3p was not studied in these types of tumors. No miRNA was deregulated in more than two types of exclusively HPV-positive tumors (Figure 2c, Table S3). Therefore, our results do not support the existence of universal "Core HPV" miRNAs whose deregulation is dependent on HPV infection.

In our set of seven SCC types, the highest similarity in miRNA deregulation was detected between cervical and HPV-negative vulvar tumors. These tumors exhibited the largest total numbers of deregulated miRNAs (Figure 2a). Of all the miRNAs deregulated in HPV-negative vulvar tumors, $69 \%$ and $76 \%$ (upregulated and downregulated miRNAs, respectively) were also deregulated in cervical tumors. Twenty-nine upregulated miRNAs and 42 downregulated miRNAs exhibited exclusive deregulation in both cervical and vulvar HPV-negative tumors (Figure 2c). For these miRNAs, we mined available literature for experimental evidence of their role in carcinogenesis of SCCs, i.e., of the effect on cell proliferation and invasiveness. While information was lacking for most upregulated miRNAs, $81 \%$ of downregulated miRNAs were experimentally characterized (Table 2). Of these 34 miRNAs, 30 were determined to function as tumor suppressors (17-in cervical carcinomas, 13-in other types of SCCs); their downregulation observed here is thus in line with their carcinogenic role in SCCs. Since the widespread downregulation of tumor suppressor miRNAs in vulvar HPV-negative tumors is independent of HPV infection, it should be considered convergent with cervical tumors.

Unless diagnosed early, cervical cancers are notorious for their poor prognosis; the otherwise high mortality is kept in check only by strenuous screening and HPV vaccination. In our set of SCCs, cervical carcinomas exhibited the most extensive miRNA deregulation (Figure 2a). Among vulvar carcinomas, the prognosis (survival rate) of HPV-negative tumors is far worse than that of HPV-positive tumors [85,86]; due to additional differences other than HPV status, both types of vulvar carcinomas are regarded as separate rather than related cancer types [87]. With respect to the total extent of miRNA deregulation, vulvar SCCs with differing HPV status are fundamentally different (extensive vs. negligible deregulation; Figure 2a); our findings thus tentatively suggest that the pattern of miRNA deregulation might be linked to the severity of gynecological malignancies. The current understanding of molecular mechanisms of vulvar carcinogenesis is extremely limited [88]. The downregulation of multiple tumor suppressor miRNAs detected in this study suggests a possible mechanism contributing to a severe course of vulvar HPV-negative cancers. Interestingly, differences in the prognosis [33] and miRNA deregulation pattern [32] were also previously found between HPV-positive and HPV-negative tonsillar tumors, although their potential connection has not been investigated yet. 


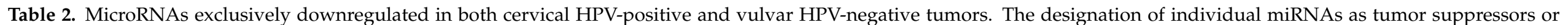

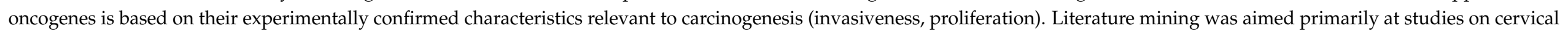
cancers; if none were available, experimental evidence for other types of SCCs was collected.

\begin{tabular}{|c|c|c|c|c|c|c|c|c|c|}
\hline \multirow[b]{2}{*}{ Gene } & \multirow[b]{2}{*}{ miRNA } & \multicolumn{2}{|c|}{ Cervical Cancer } & \multicolumn{2}{|c|}{ Vulvar HPV-Negative Cancer } & \multirow[b]{2}{*}{ Function in SCCs } & \multirow[b]{2}{*}{ SCC Type ${ }^{1}$} & \multirow[b]{2}{*}{ Targets } & \multirow[b]{2}{*}{ References } \\
\hline & & $\begin{array}{c}\text { FC of } \\
\text { Expression }\end{array}$ & padj & $\begin{array}{c}\text { FC of } \\
\text { Expression }\end{array}$ & padj & & & & \\
\hline hsa-miR-103b & MIR103B1 & 16.8 & $1.2 \times 10^{-4}$ & 11.3 & $4.7 \times 10^{-3}$ & Tumor suppressor & OSCC & SALL4 & [89] \\
\hline hsa-miR-107 & MIR107 & 15.8 & $8.6 \times 10^{-3}$ & 12.9 & $1.5 \times 10^{-2}$ & Tumor suppressor & $\mathrm{CC}$ & MCL1 & {$[90]$} \\
\hline hsa-miR-125b-5p & MIR125B1 & 6.4 & $1.8 \times 10^{-3}$ & 14.6 & $3.7 \times 10^{-7}$ & Tumor suppressor & $\mathrm{CC}$ & PIK3CD & [91] \\
\hline hsa-miR-136-3p & MIR136 & 31.6 & $1.0 \times 10^{-7}$ & 6.5 & $1.1 \times 10^{-2}$ & Tumor suppressor & $\mathrm{CC}$ & E2F1 & [92] \\
\hline hsa-miR-148a-3p & MIR148A & 22.4 & $3.2 \times 10^{-8}$ & 13.3 & $4.7 \times 10^{-5}$ & Tumor suppressor & ESCC, OSCC & MAP3K9, IGF1R & {$[93,94]$} \\
\hline hsa-miR-152-3p & MIR152 & 11.8 & $8.8 \times 10^{-5}$ & 3.7 & $6.8 \times 10^{-2}$ & Tumor suppressor & CC & KLF5 & [96] \\
\hline hsa-miR-16-5p & MIR16-1 & 7.2 & $3.8 \times 10^{-3}$ & 10.8 & $1.8 \times 10^{-4}$ & Tumor suppressor & OscC & AKT3, BCL2L2 & [97] \\
\hline hsa-miR-17-5p & MIR17 & 22.3 & $6.4 \times 10^{-3}$ & 11.0 & $3.7 \times 10^{-2}$ & Tumor suppressor & CC & TP53INP1 & [98] \\
\hline hsa-miR-199a-3p & MIR199A1 & 38.2 & $4.4 \times 10^{-9}$ & 10.7 & $9.3 \times 10^{-4}$ & Tumor suppressor & HNSCC & ITGA3 & [99] \\
\hline hsa-miR-199a-5p & MIR199A1 & 4.8 & $2.0 \times 10^{-3}$ & 4.5 & $1.2 \times 10^{-2}$ & Tumor suppressor & HNSCC, OSCC & SOX4, IKK2, ITGA3 & [99-101] \\
\hline hsa-miR-199b-3p & MIR199B & 34.1 & $7.8 \times 10^{-9}$ & 10.6 & $9.3 \times 10^{-4}$ & Tumor suppressor & HNSCC & ITGA3 & [99] \\
\hline hsa-miR-199b-5p & MIR199B & 13.1 & $3.2 \times 10^{-8}$ & 9.3 & $3.2 \times 10^{-4}$ & Tumor suppressor & HNSCC & ITGA3 & [99] \\
\hline hsa-miR-211-5p & MIR211 & 15.6 & $3.0 \times 10^{-2}$ & 58.2 & $2.4 \times 10^{-5}$ & Tumor suppressor & $\mathrm{CC}$ & SPARC & [102] \\
\hline hsa-miR-218-5p & MIR218-1 & 11.4 & $1.2 \times 10^{-3}$ & 4.3 & $9.3 \times 10^{-2}$ & Tumor suppressor & $\mathrm{CC}$ & IDO1 & [103] \\
\hline hsa-miR-23a-3p & MIR23A & 3.7 & $1.9 \times 10^{-2}$ & 3.2 & $6.8 \times 10^{-2}$ & Tumor suppressor & OsCC & FGF2 & [105] \\
\hline hsa-miR-24-3p & MIR24-1 & 7.5 & $3.0 \times 10^{-4}$ & 9.9 & $9.3 \times 10^{-4}$ & Tumor suppressor & LSCC & S100A8, XIAP & {$[106,107]$} \\
\hline hsa-miR-27a-3p & MIR27A & 4.0 & $6.0 \times 10^{-3}$ & 3.2 & $4.5 \times 10^{-2}$ & Tumor suppressor & CC & TGFBRI & [108] \\
\hline hsa-miR-27b-3p & MIR27B & 5.5 & $2.9 \times 10^{-3}$ & 6.8 & $1.3 \times 10^{-3}$ & Tumor suppressor & ESCC & NFE2L2 & [109] \\
\hline hsa-miR-30d-5p & MIR30D & 2.4 & $7.7 \times 10^{-2}$ & 2.7 & $7.6 \times 10^{-2}$ & Tumor suppressor & ESCC & EZH2 & [110] \\
\hline hsa-miR-33a-5p & MIR33A & 6.0 & $3.6 \times 10^{-2}$ & 12.2 & $2.8 \times 10^{-2}$ & Tumor suppressor & CC & TWIST1 & [111] \\
\hline hsa-miR-376c-3p & MIR376C & 45.4 & $9.0 \times 10^{-6}$ & 12.8 & $1.8 \times 10^{-2}$ & Tumor suppressor & $\mathrm{CC}$ & BMI1 & [112] \\
\hline hsa-miR-411-5p & MIR411 & 67.3 & $4.1 \times 10^{-5}$ & 8.9 & $6.6 \times 10^{-2}$ & Tumor suppressor & $\mathrm{CC}$ & STAT3 & [113] \\
\hline hsa-miR-99a-3p & MIR99A & 12.5 & $6.7 \times 10^{-4}$ & 26.9 & $1.1 \times 10^{-3}$ & Tumor suppressor & $\mathrm{CC}$ & TRIB2 & [114] \\
\hline hsa-miR-99a-5p & MIR99A & 4.2 & $4.4 \times 10^{-2}$ & 17.7 & $3.7 \times 10^{-7}$ & Tumor suppressor & $\mathrm{CC}$ & TRIB2 & [114] \\
\hline hsa-let-7a-5p & MIRLET7A1 & 9.5 & $2.5 \times 10^{-4}$ & 9.0 & $9.3 \times 10^{-4}$ & Tumor suppressor & $\mathrm{CC}$ & PKM2, TGFBR1 & {$[115,116]$} \\
\hline
\end{tabular}


Table 2. Cont.

\begin{tabular}{|c|c|c|c|c|c|c|c|c|c|}
\hline \multirow[b]{2}{*}{ Gene } & \multirow[b]{2}{*}{ miRNA } & \multicolumn{2}{|c|}{ Cervical Cancer } & \multicolumn{2}{|c|}{ Vulvar HPV-Negative Cancer } & \multirow[b]{2}{*}{ Function in SCCs } & \multirow[b]{2}{*}{ SCC Type ${ }^{1}$} & \multirow[b]{2}{*}{ Targets } & \multirow[b]{2}{*}{ References } \\
\hline & & $\begin{array}{c}\text { FC of } \\
\text { Expression }\end{array}$ & padj & $\begin{array}{c}\text { FC of } \\
\text { Expression }\end{array}$ & padj & & & & \\
\hline hsa-let-7b-5p & MIRLET7B & 4.3 & $2.4 \times 10^{-3}$ & 2.7 & $7.7 \times 10^{-2}$ & Tumor suppressor & $\mathrm{CC}$ & KIAA1377 & [117] \\
\hline hsa-let-7c-5p & MIRLET7C & 14.0 & $4.0 \times 10^{-5}$ & 11.8 & $2.4 \times 10^{-5}$ & Tumor suppressor & ESCC, HNSCC & $\begin{array}{c}\text { CTHRC1, IGF1R, } \\
\text { HMGA2 }\end{array}$ & {$[118,119]$} \\
\hline hsa-let-7e-5p & MIRLET7E & 19.3 & $3.4 \times 10^{-4}$ & 5.8 & $3.7 \times 10^{-2}$ & Tumor suppressor & HNSCC & CCR7 & [120] \\
\hline hsa-miR-106b-5p & MIR106B & 6.2 & $3.8 \times 10^{-2}$ & 8.4 & $3.0 \times 10^{-2}$ & oncogene & CC & DAB2 & [121] \\
\hline hsa-miR-130a-3p & MIR130A & 37.4 & $1.6 \times 10^{-8}$ & 8.4 & $6.9 \times 10^{-3}$ & oncogene & $\mathrm{CC}$ & RUNX3 & [122] \\
\hline hsa-miR-4454 & MIR4454 & 7.8 & $3.3 \times 10^{-4}$ & 5.2 & $2.6 \times 10^{-2}$ & oncogene & CC & ABHD2, NUDT21 & [124] \\
\hline hsa-miR-191-5p & MIR191 & 8.0 & $5.2 \times 10^{-5}$ & 5.8 & $2.8 \times 10^{-3}$ & n.d. & & & \\
\hline hsa-miR-3074-5p & MIR3074 & 7.5 & $3.0 \times 10^{-4}$ & 9.9 & $9.3 \times 10^{-4}$ & n.d. & & & \\
\hline hsa-miR-3195 & MIR3195 & 3.0 & $9.2 \times 10^{-2}$ & 3.6 & $5.7 \times 10^{-2}$ & n.d. & & & \\
\hline hsa-miR-4286 & MIR4286 & 5.2 & $5.1 \times 10^{-2}$ & 6.0 & $4.1 \times 10^{-2}$ & n.d. & & & \\
\hline hsa-miR-6510-3p & MIR6510 & 10.7 & $4.3 \times 10^{-2}$ & 13.4 & $1.9 \times 10^{-2}$ & n.d. & & & \\
\hline hsa-miR-660-5p & MIR660 & 20.0 & $5.7 \times 10^{-4}$ & 7.1 & $3.4 \times 10^{-2}$ & n.d. & & & \\
\hline hsa-miR-887-3p & MIR887 & 8.8 & $1.7 \times 10^{-3}$ & 4.2 & $3.5 \times 10^{-2}$ & n.d. & & & \\
\hline
\end{tabular}

${ }^{1}$ CC: cervical carcinoma; ESCC: esophageal SCC; HNSCC: head and neck SCC; LSCC: laryngeal SCC; OSCC: oral SCC; n.d.: not determined (no experimental evidence for SCC available). 
In conclusion, this study demonstrates that miRNA deregulation in various SCC types is largely tumor-specific and that the HPV status of SCCs is not a determinant of either the extent or the composition of the deregulated miRNA pool. Our findings may provide useful directions for further studies on the pathogenesis of individual types of SCCs with respect to their differences in anatomical location and HPV status.

Supplementary Materials: The following are available online at https://www.mdpi.com/article/10 .3390 / biom11050764/s1, Table S1: Yields of sequencing reads in sample tissues, Table S2: Relative expression of miRNAs in sample tissues, Table S3: Differentially expressed miRNAs in different tumor types.

Author Contributions: Conceptualization, R.T. and Z.V.; Methodology, R.T. and Z.V.; Formal analysis, J.N.; Investigation, L.P., N.T.D.d.A., M.S., and J.S.; Writing-original draft preparation, J.N. and Z.V.; Writing-review and editing, L.P., N.T.D.d.A., M.S., J.S. and R.T.; Visualization, J.N.; Supervision, R.T.; Project administration, R.T.; Funding acquisition, R.T. and Z.V. All authors have read and agreed to the published version of the manuscript.

Funding: This research was funded by the Charles University, Prague, project GA UK No. 80318, and the European Regional Development Fund and the Ministry of Education, Youth and Sports of the Czech Republic, grant number CZ.02.1.01/0.0/0.0/16_019/0000785.

Institutional Review Board Statement: The study was conducted according to the guidelines of the Declaration of Helsinki under official institutional and ethical approvals issued for previous studies.

Informed Consent Statement: Informed consent was obtained from all the subjects involved in the study.

Data Availability Statement: Data supporting the presented results are available in three supplementary tables. Sequencing reads were deposited in the SRA, GenBank (BioProject ID: PRJNA718204).

Acknowledgments: We thank Petr Skapa, Marek Grega (2nd Faculty of Medicine, Charles University and Motol University Hospital) and Libor Stanek (3rd Faculty of Medicine, Charles University and University Hospital Kralovske Vinohrady) for their help with sample selection. Dominika Kadleckova is acknowledged for the Adonis-Bray analysis.

Conflicts of Interest: The authors declare no conflict of interest. The funders had no role in the design of the study; in the collection, analyses, or interpretation of data; in the writing of the manuscript, or in the decision to publish the results.

\section{References}

1. Plummer, M.; de Martel, C.; Vignat, J.; Ferlay, J.; Bray, F.; Franceschi, S. Global burden of cancers attributable to infections in 2012: A synthetic analysis. Lancet Glob. Health 2016, 4, e609-e616. [CrossRef]

2. de Martel, C.; Plummer, M.; Vignat, J.; Franceschi, S. Worldwide burden of cancer attributable to HPV by site, country and HPV type. Int. J. Cancer 2017, 141, 664-670. [CrossRef] [PubMed]

3. Nordfors, C.; Vlastos, A.; Du, J.; Ahrlund-Richter, A.; Tertipis, N.; Grün, N.; Romanitan, M.; Haeggblom, L.; Roosaar, A.; Dahllöf, G.; et al. Human papillomavirus prevalence is high in oral samples of patients with tonsillar and base of tongue cancer. Oral Oncol. 2014, 50, 491-497. [CrossRef] [PubMed]

4. Marur, S.; D'Souza, G.; Westra, W.H.; Forastiere, A.A. HPV-associated head and neck cancer: A virus-related cancer epidemic. Lancet Oncol. 2010, 11, 781-789. [CrossRef]

5. Näsman, A.; Attner, P.; Hammarstedt, L.; Du, J.; Eriksson, M.; Giraud, G.; Ahrlund-Richter, S.; Marklund, L.; Romanitan, M.; Lindquist, D.; et al. Incidence of human papillomavirus (HPV) positive tonsillar carcinoma in Stockholm, Sweden: An epidemic of viral-induced carcinoma? Int. J. Cancer 2009, 125, 362-366. [CrossRef]

6. Tachezy, R.; Klozar, J.; Rubenstein, L.; Smith, E.; Saláková, M.; Smahelová, J.; Ludvíková, V.; Rotnáglová, E.; Kodet, R.; Hamsíková, E. Demographic and risk factors in patients with head and neck tumors. J. Med. Virol. 2009, 81, 878-887. [CrossRef]

7. Koncar, R.F.; Feldman, R.; Bahassi, E.M.; Hashemi Sadraei, N. Comparative molecular profiling of HPV-induced squamous cell carcinomas. Cancer Med. 2017, 6, 1673-1685. [CrossRef] [PubMed]

8. Tuna, M.; Amos, C.I. Next generation sequencing and its applications in HPV-associated cancers. Oncotarget 2017, 8, 8877-8889. [CrossRef]

9. Gillison, M.L.; Akagi, K.; Xiao, W.; Jiang, B.; Pickard, R.K.L.; Li, J.; Swanson, B.J.; Agrawal, A.D.; Zucker, M.; Stache-Crain, B.; et al. Human papillomavirus and the landscape of secondary genetic alterations in oral cancers. Genome Res. 2019, 29, 1-17. [CrossRef]

10. Haeggblom, L.; Ährlund-Richter, A.; Mirzaie, L.; Farrajota Neves da Silva, P.; Ursu, R.G.; Ramqvist, T.; Näsman, A. Differences in gene expression between high-grade dysplasia and invasive HPV. Cancer Med. 2019, 8, 6221-6232. [CrossRef] 
11. Seiwert, T.Y.; Zuo, Z.; Keck, M.K.; Khattri, A.; Pedamallu, C.S.; Stricker, T.; Brown, C.; Pugh, T.J.; Stojanov, P.; Cho, J.; et al. Integrative and comparative genomic analysis of HPV-positive and HPV-negative head and neck squamous cell carcinomas. Clin. Cancer Res. 2015, 21, 632-641. [CrossRef] [PubMed]

12. Han, M.R.; Shin, S.; Park, H.C.; Kim, M.S.; Lee, S.H.; Jung, S.H.; Song, S.Y.; Chung, Y.J. Mutational signatures and chromosome alteration profiles of squamous cell carcinomas of the vulva. Exp. Mol. Med. 2018, 50, e442. [CrossRef] [PubMed]

13. Prieske, K.; Alawi, M.; Oliveira-Ferrer, L.; Jaeger, A.; Eylmann, K.; Burandt, E.; Schmalfeldt, B.; Joosse, S.A.; Woelber, L. Genomic characterization of vulvar squamous cell carcinoma. Gynecol. Oncol. 2020, 158, 547-554. [CrossRef] [PubMed]

14. Calin, G.A.; Dumitru, C.D.; Shimizu, M.; Bichi, R.; Zupo, S.; Noch, E.; Aldler, H.; Rattan, S.; Keating, M.; Rai, K.; et al. Frequent deletions and down-regulation of micro- RNA genes miR15 and miR16 at 13q14 in chronic lymphocytic leukemia. Proc. Natl. Acad. Sci. USA 2002, 99, 15524-15529. [CrossRef]

15. Ferracin, M.; Pedriali, M.; Veronese, A.; Zagatti, B.; Gafà, R.; Magri, E.; Lunardi, M.; Munerato, G.; Querzoli, G.; Maestri, I.; et al. MicroRNA profiling for the identification of cancers with unknown primary tissue-of-origin. J. Pathol. 2011, 225, 43-53. [CrossRef]

16. Iorio, M.V.; Ferracin, M.; Liu, C.G.; Veronese, A.; Spizzo, R.; Sabbioni, S.; Magri, E.; Pedriali, M.; Fabbri, M.; Campiglio, M.; et al. MicroRNA gene expression deregulation in human breast cancer. Cancer Res. 2005, 65, 7065-7070. [CrossRef]

17. Porkka, K.P.; Pfeiffer, M.J.; Waltering, K.K.; Vessella, R.L.; Tammela, T.L.; Visakorpi, T. MicroRNA expression profiling in prostate cancer. Cancer Res. 2007, 67, 6130-6135. [CrossRef]

18. Yanaihara, N.; Caplen, N.; Bowman, E.; Seike, M.; Kumamoto, K.; Yi, M.; Stephens, R.M.; Okamoto, A.; Yokota, J.; Tanaka, T.; et al. Unique microRNA molecular profiles in lung cancer diagnosis and prognosis. Cancer Cell 2006, 9, 189-198. [CrossRef]

19. Lajer, C.B.; Garnæs, E.; Friis-Hansen, L.; Norrild, B.; Therkildsen, M.H.; Glud, M.; Rossing, M.; Lajer, H.; Svane, D.; Skotte, L.; et al. The role of miRNAs in human papilloma virus (HPV)-associated cancers: Bridging between HPV-related head and neck cancer and cervical cancer. Br. J. Cancer 2012, 106, 1526-1534. [CrossRef]

20. Pereira, P.M.; Marques, J.P.; Soares, A.R.; Carreto, L.; Santos, M.A. MicroRNA expression variability in human cervical tissues. PLoS ONE 2010, 5, e11780. [CrossRef]

21. Rao, Q.; Shen, Q.; Zhou, H.; Peng, Y.; Li, J.; Lin, Z. Aberrant microRNA expression in human cervical carcinomas. Med. Oncol. 2012, 29, 1242-1248. [CrossRef] [PubMed]

22. Snoek, B.C.; Verlaat, W.; Babion, I.; Novianti, P.W.; van de Wiel, M.A.; Wilting, S.M.; van Trommel, N.E.; Bleeker, M.C.G.; Massuger, L.F.A.G.; Melchers, W.J.G.; et al. Genome-wide microRNA analysis of HPV-positive self-samples yields novel triage markers for early detection of cervical cancer. Int. J. Cancer 2019, 144, 372-379. [CrossRef] [PubMed]

23. de Melo Maia, B.; Lavorato-Rocha, A.M.; Rodrigues, L.S.; Coutinho-Camillo, C.M.; Baiocchi, G.; Stiepcich, M.M.; Puga, R.; de A Lima, L.; Soares, F.A.; Rocha, R.M. MicroRNA portraits in human vulvar carcinoma. Cancer Prev. Res. (Phila) 2013, 6, 1231-1241. [CrossRef] [PubMed]

24. Yang, X.; Wu, X. MiRNA expression profile of vulvar squamous cell carcinoma and identification of the oncogenic role of miR-590-5p. Oncol. Rep. 2016, 35, 398-408. [CrossRef]

25. Avissar, M.; Christensen, B.C.; Kelsey, K.T.; Marsit, C.J. MicroRNA expression ratio is predictive of head and neck squamous cell carcinoma. Clin. Cancer Res. 2009, 15, 2850-2855. [CrossRef]

26. Chang, S.S.; Jiang, W.W.; Smith, I.; Poeta, L.M.; Begum, S.; Glazer, C.; Shan, S.; Westra, W.; Sidransky, D.; Califano, J.A. MicroRNA alterations in head and neck squamous cell carcinoma. Int. J. Cancer 2008, 123, 2791-2797. [CrossRef]

27. Childs, G.; Fazzari, M.; Kung, G.; Kawachi, N.; Brandwein-Gensler, M.; McLemore, M.; Chen, Q.; Burk, R.D.; Smith, R.V.; Prystowsky, M.B.; et al. Low-level expression of microRNAs let-7d and miR-205 are prognostic markers of head and neck squamous cell carcinoma. Am. J. Pathol. 2009, 174, 736-745. [CrossRef]

28. Hui, A.B.; Lenarduzzi, M.; Krushel, T.; Waldron, L.; Pintilie, M.; Shi, W.; Perez-Ordonez, B.; Jurisica, I.; O'Sullivan, B.; Waldron, J.; et al. Comprehensive MicroRNA profiling for head and neck squamous cell carcinomas. Clin. Cancer Res. 2010, 16, 1129-1139. [CrossRef]

29. Ramdas, L.; Giri, U.; Ashorn, C.L.; Coombes, K.R.; El-Naggar, A.; Ang, K.K.; Story, M.D. MiRNA expression profiles in head and neck squamous cell carcinoma and adjacent normal tissue. Head Neck 2009, 31, 642-654. [CrossRef]

30. Lajer, C.B.; Nielsen, F.C.; Friis-Hansen, L.; Norrild, B.; Borup, R.; Garnæs, E.; Rossing, M.; Specht, L.; Therkildsen, M.H.; Nauntofte, B.; et al. Different miRNA signatures of oral and pharyngeal squamous cell carcinomas: A prospective translational study. Br. J. Cancer 2011, 104, 830-840. [CrossRef]

31. Miller, D.L.; Davis, J.W.; Taylor, K.H.; Johnson, J.; Shi, Z.; Williams, R.; Atasoy, U.; Lewis, J.S.; Stack, M.S. Identification of a human papillomavirus-associated oncogenic miRNA panel in human oropharyngeal squamous cell carcinoma validated by bioinformatics analysis of the Cancer Genome Atlas. Am. J. Pathol. 2015, 185, 679-692. [CrossRef]

32. Vojtechova, Z.; Sabol, I.; Salakova, M.; Smahelova, J.; Zavadil, J.; Turek, L.; Grega, M.; Klozar, J.; Prochazka, B.; Tachezy, R. Comparison of the miRNA profiles in HPV-positive and HPV-negative tonsillar tumors and a model system of human keratinocyte clones. BMC Cancer 2016, 16, 382. [CrossRef] [PubMed]

33. Rotnáglová, E.; Tachezy, R.; Saláková, M.; Procházka, B.; Košl’abová, E.; Veselá, E.; Ludvíková, V.; Hamšíková, E.; Klozar, J. HPV involvement in tonsillar cancer: Prognostic significance and clinically relevant markers. Int. J. Cancer 2011, 129, 101-110. [CrossRef] [PubMed] 
34. Kearse, M.; Moir, R.; Wilson, A.; Stones-Havas, S.; Cheung, M.; Sturrock, S.; Buxton, S.; Cooper, A.; Markowitz, S.; Duran, C.; et al. Geneious Basic: An integrated and extendable desktop software platform for the organization and analysis of sequence data. Bioinformatics 2012, 28, 1647-1649. [CrossRef]

35. Love, M.I.; Huber, W.; Anders, S. Moderated estimation of fold change and dispersion for RNA-seq data with DESeq2. Genome Biol. 2014, 15, 550. [CrossRef] [PubMed]

36. Oksanen, J.; Blanchet, F.G.; Friendly, M.; Kindt, R.; Legendre, P.; McGlinn, D.; Minchin, P.R.; O'Hara, R.; Simpson, G.; Solymos, P. Vegan: Community Ecology Package. R Package Version 2.5-6. 2019. Available online: https://github.com/vegandevs/vegan (accessed on 1 January 2021).

37. Lu, J.; Getz, G.; Miska, E.A.; Alvarez-Saavedra, E.; Lamb, J.; Peck, D.; Sweet-Cordero, A.; Ebert, B.L.; Mak, R.H.; Ferrando, A.A.; et al. MicroRNA expression profiles classify human cancers. Nature 2005, 435, 834-838. [CrossRef]

38. Ludwig, N.; Leidinger, P.; Becker, K.; Backes, C.; Fehlmann, T.; Pallasch, C.; Rheinheimer, S.; Meder, B.; Stähler, C.; Meese, E.; et al. Distribution of miRNA expression across human tissues. Nucleic Acids Res. 2016, 44, 3865-3877. [CrossRef] [PubMed]

39. Panwar, B.; Omenn, G.S.; Guan, Y. miRmine: A database of human miRNA expression profiles. Bioinformatics 2017, 33, 1554-1560. [CrossRef]

40. Volinia, S.; Calin, G.A.; Liu, C.G.; Ambs, S.; Cimmino, A.; Petrocca, F.; Visone, R.; Iorio, M.; Roldo, C.; Ferracin, M.; et al. A microRNA expression signature of human solid tumors defines cancer gene targets. Proc. Natl. Acad. Sci. USA 2006, 103, 2257-2261. [CrossRef] [PubMed]

41. Metsalu, T.; Vilo, J. ClustVis: A web tool for visualizing clustering of multivariate data using Principal Component Analysis and heatmap. Nucleic Acids Res. 2015, 43, W566-W570. [CrossRef]

42. Gong, J.; Chu, Y.; Xu, M.; Huo, J.; Lv, L. Esophageal squamous cell carcinoma cell proliferation induced by exposure to low concentration of cigarette smoke extract is mediated via targeting miR-101-3p/COX-2 pathway. Oncol. Rep. 2016, 35, 463-471. [CrossRef] [PubMed]

43. Huang, F.; Lin, C.; Shi, Y.H.; Kuerban, G. MicroRNA-101 inhibits cell proliferation, invasion, and promotes apoptosis by regulating cyclooxygenase-2 in Hela cervical carcinoma cells. Asian Pac. J. Cancer Prev. 2013, 14, 5915-5920. [CrossRef]

44. Li, M.; Tian, L.; Ren, H.; Chen, X.; Wang, Y.; Ge, J.; Wu, S.; Sun, Y.; Liu, M.; Xiao, H. MicroRNA-101 is a potential prognostic indicator of laryngeal squamous cell carcinoma and modulates CDK8. J. Transl. Med. 2015, 13, 271. [CrossRef]

45. Chen, L.; Jia, J.; Zang, Y.; Li, J.; Wan, B. MicroRNA-101 regulates autophagy, proliferation and apoptosis via targeting EZH2 in laryngeal squamous cell carcinoma. Neoplasma 2019, 66, 507-515. [CrossRef] [PubMed]

46. Lin, C.; Huang, F.; Shen, G.; Yiming, A. MicroRNA-101 regulates the viability and invasion of cervical cancer cells. Int. J. Clin. Exp. Pathol. 2015, 8, 10148-10155. [PubMed]

47. Wei, H.; He, W.R.; Chen, K.M.; Wang, X.W.; Yi, C.J. MiR-101 affects proliferation and apoptosis of cervical cancer cells by inhibition of JAK2. Eur. Rev. Med. Pharmacol. Sci. 2019, 23, 5640-5647. [CrossRef]

48. Liang, X.; Liu, Y.; Zeng, L.; Yu, C.; Hu, Z.; Zhou, Q.; Yang, Z. MiR-101 inhibits the G1-to-S phase transition of cervical cancer cells by targeting Fos. Int. J. Gynecol. Cancer 2014, 24, 1165-1172. [CrossRef]

49. Hui, Y.; Li, Y.; Jing, Y.; Feng, J.Q.; Ding, Y. MiRNA-101 acts as a tumor suppressor in oral squamous cell carcinoma by targeting CX chemokine receptor 7. Am. J. Transl. Res. 2016, 8, 4902-4911. [PubMed]

50. Wu, B.; Lei, D.; Wang, L.; Yang, X.; Jia, S.; Yang, Z.; Shan, C.; Zhang, C.; Lu, B. MiRNA-101 inhibits oral squamous-cell carcinoma growth and metastasis by targeting zinc finger E-box binding homeobox 1. Am. J. Cancer Res. 2016, 6, $1396-1407$.

51. Wang, Y.; Jia, R.Z.; Diao, S.; He, J.; Jia, L. MiRNA-101 targets TGF- $\beta$ R1 to retard the progression of oral squamous cell carcinoma. Oncol. Res. 2020, 28, 203-212. [CrossRef]

52. Wang, X.; Li, M.; Wang, Z.; Han, S.; Tang, X.; Ge, Y.; Zhou, L.; Zhou, C.; Yuan, Q.; Yang, M. Silencing of long noncoding RNA MALAT1 by miR-101 and miR-217 inhibits proliferation, migration, and invasion of esophageal squamous cell carcinoma cells. J. Biol. Chem. 2015, 290, 3925-3935. [CrossRef] [PubMed]

53. Zou, D.; Zhou, Q.; Wang, D.; Guan, L.; Yuan, L.; Li, S. The downregulation of microRNA-10b and its role in cervical cancer. Oncol. Res. 2016, 24, 99-108. [CrossRef] [PubMed]

54. Hou, R.; Wang, D.; Lu, J. MicroRNA-10b inhibits proliferation, migration and invasion in cervical cancer cells via direct targeting of insulin-like growth factor-1 receptor. Oncol. Lett. 2017, 13, 5009-5015. [CrossRef] [PubMed]

55. Yu, M.; Xu, Y.; Pan, L.; Feng, Y.; Luo, K.; Mu, Q.; Luo, G. MiR-10b downregulated by DNA methylation acts as a tumor suppressor in HPV-positive cervical cancer via targeting Tiam1. Cell Physiol. BioChem. 2018, 51, 1763-1777. [CrossRef] [PubMed]

56. Kinoshita, T.; Nohata, N.; Hanazawa, T.; Kikkawa, N.; Yamamoto, N.; Yoshino, H.; Itesako, T.; Enokida, H.; Nakagawa, M.; Okamoto, Y.; et al. Tumour-suppressive microRNA-29s inhibit cancer cell migration and invasion by targeting laminin-integrin signalling in head and neck squamous cell carcinoma. Br. J. Cancer 2013, 109, 2636-2645. [CrossRef]

57. Ding, D.P.; Chen, Z.L.; Zhao, X.H.; Wang, J.W.; Sun, J.; Wang, Z.; Tan, F.W.; Tan, X.G.; Li, B.Z.; Zhou, F.; et al. MiR-29c induces cell cycle arrest in esophageal squamous cell carcinoma by modulating cyclin E expression. Carcinogenesis 2011, 32, 1025-1032. [CrossRef]

58. Chen, C.; Tang, J.; Xu, S.; Zhang, W.; Jiang, H. MiR-30a-5p inhibits proliferation and migration of lung squamous cell carcinoma cells by targeting FOXD1. Biomed. Res. Int. 2020, 2020, 2547902. [CrossRef] 
59. Qi, B.; Wang, Y.; Chen, Z.J.; Li, X.N.; Qi, Y.; Yang, Y.; Cui, G.H.; Guo, H.Z.; Li, W.H.; Zhao, S. Down-regulation of miR-30a-3p/5p promotes esophageal squamous cell carcinoma cell proliferation by activating the Wnt signaling pathway. World J. Gastroenterol. 2017, 23, 7965-7977. [CrossRef]

60. Zhao, J.; Li, B.; Shu, C.; Ma, Y.; Gong, Y. Downregulation of miR-30a is associated with proliferation and invasion via targeting MEF2D in cervical cancer. Oncol. Lett. 2017, 14, 7437-7442. [CrossRef]

61. Fukumoto, I.; Kinoshita, T.; Hanazawa, T.; Kikkawa, N.; Chiyomaru, T.; Enokida, H.; Yamamoto, N.; Goto, Y.; Nishikawa, R.; Nakagawa, M.; et al. Identification of tumour suppressive microRNA-451a in hypopharyngeal squamous cell carcinoma based on microRNA expression signature. Br. J. Cancer 2014, 111, 386-394. [CrossRef]

62. Fu, J.; Zhao, J.; Zhang, H.; Fan, X.; Geng, W.; Qiao, S. MicroRNA-451a prevents cutaneous squamous cell carcinoma progression via the 3-phosphoinositide-dependent protein kinase-1-mediated PI3K/AKT signaling pathway. Exp. Ther. Med. 2021, 21, 116. [CrossRef] [PubMed]

63. Zang, W.Q.; Yang, X.; Wang, T.; Wang, Y.Y.; Du, Y.W.; Chen, X.N.; Li, M.; Zhao, G.Q. MiR-451 inhibits proliferation of esophageal carcinoma cell line EC9706 by targeting CDKN2D and MAP3K1. World J. Gastroenterol. 2015, 21, 5867-5876. [CrossRef] [PubMed]

64. Uchida, A.; Seki, N.; Mizuno, K.; Yamada, Y.; Misono, S.; Sanada, H.; Kikkawa, N.; Kumamoto, T.; Suetsugu, T.; Inoue, H. Regulation of KIF2A by antitumor miR-451a inhibits cancer cell aggressiveness features in lung squamous cell carcinoma. Cancers 2019, 11, 258. [CrossRef]

65. Liu, Y.; Liu, J.; Wang, L.; Yang, X.; Liu, X. MicroRNA-195 inhibits cell proliferation, migration and invasion in laryngeal squamous cell carcinoma by targeting ROCK1. Mol. Med. Rep. 2017, 16, 7154-7162. [CrossRef] [PubMed]

66. Shuang, Y.; Li, C.; Zhou, X.; Huang, Y.; Zhang, L. MicroRNA-195 inhibits growth and invasion of laryngeal carcinoma cells by directly targeting DCUN1D1. Oncol. Rep. 2017, 38, 2155-2165. [CrossRef] [PubMed]

67. Wang, N.; Wei, H.; Yin, D.; Lu, Y.; Zhang, Y.; Zhang, Q.; Ma, X.; Zhang, S. MicroRNA-195 inhibits proliferation of cervical cancer cells by targeting cyclin D1a. Tumor Biol. 2016, 37, 4711-4720. [CrossRef]

68. Song, R.; Cong, L.; Ni, G.; Chen, M.; Sun, H.; Sun, Y. MicroRNA-195 inhibits the behavior of cervical cancer tumors by directly targeting HDGF. Oncol. Lett. 2017, 14, 767-775. [CrossRef]

69. DU, X.; Lin, L.I.; Zhang, L.; Jiang, J. MicroRNA-195 inhibits the proliferation, migration and invasion of cervical cancer cells via the inhibition of CCND2 and MYB expression. Oncol. Lett. 2015, 10, 2639-2643. [CrossRef] [PubMed]

70. Hao, X.; Jia, Q.; Yuan, J.; Shi, X.; Guo, H.; Gao, J.; Guo, Y. MicroRNA-195 suppresses cell proliferation, migration and invasion in epithelial ovarian carcinoma via inhibition of the CDC42/CCND1 pathway. Int. J. Mol. Med. 2020, 46, 1862-1872. [CrossRef]

71. Sun, N.; Ye, L.; Chang, T.; Li, X. MicroRNA-195-Cdc42 axis acts as a prognostic factor of esophageal squamous cell carcinoma. Int. J. Clin. Exp. Pathol. 2014, 7, 6871-6879.

72. Liu, W.; Wang, J.; Meng, N.; Wang, X.; Ge, D. MiR-195 inhibits proliferation of oral squamous cell carcinoma cells through regulating Smad7. Panminerva Med. 2020. [CrossRef]

73. Zhou, Q.; Han, L.R.; Zhou, Y.X.; Li, Y. MiR-195 suppresses cervical cancer migration and invasion through targeting Smad3. Int. J. Gynecol. Cancer 2016, 26, 817-824. [CrossRef] [PubMed]

74. Liu, H.; Chen, Y.; Li, Y.; Li, C.; Qin, T.; Bai, M.; Zhang, Z.; Jia, R.; Su, Y.; Wang, C. MiR-195 suppresses metastasis and angiogenesis of squamous cell lung cancer by inhibiting the expression of VEGF. Mol. Med. Rep. 2019, 20, 2625-2632. [CrossRef]

75. Liu, X.; Zhou, Y.; Ning, Y.E.; Gu, H.; Tong, Y.; Wang, N. MiR-195-5p inhibits malignant progression of cervical cancer by targeting YAP1. Onco Targets Ther. 2020, 13, 931-944. [CrossRef]

76. Pan, S.S.; Zhou, H.E.; Yu, H.Y.; Xu, L.H. MiR-195-5p inhibits the cell migration and invasion of cervical carcinoma through suppressing ARL2. Eur. Rev. Med. Pharmacol. Sci. 2019, 23, 10664-10671. [CrossRef]

77. Wang, T.; Ren, Y.; Liu, R.; Ma, J.; Shi, Y.; Zhang, L.; Bu, R. MiR-195-5p suppresses the proliferation, migration, and invasion of oral squamous cell carcinoma by targeting TRIM14. Biomed. Res. Int. 2017, 2017, 7378148. [CrossRef] [PubMed]

78. Jia, L.F.; Wei, S.B.; Gong, K.; Gan, Y.H.; Yu, G.Y. Prognostic implications of micoRNA miR-195 expression in human tongue squamous cell carcinoma. PLoS ONE 2013, 8, e56634. [CrossRef] [PubMed]

79. Heberle, H.; Meirelles, G.V.; da Silva, F.R.; Telles, G.P.; Minghim, R. InteractiVenn: A web-based tool for the analysis of sets through Venn diagrams. BMC Bioinform. 2015, 16, 169. [CrossRef]

80. Iacona, J.R.; Lutz, C.S. miR-146a-5p: Expression, regulation, and functions in cancer. Wiley Interdiscip. Rev. RNA 2019, 10, e1533. [CrossRef] [PubMed]

81. Hu, Q.; Song, J.; Ding, B.; Cui, Y.; Liang, J.; Han, S. MiR-146a promotes cervical cancer cell viability via targeting IRAK1 and TRAF6. Oncol. Rep. 2018, 39, 3015-3024. [CrossRef]

82. Gee, H.E.; Camps, C.; Buffa, F.M.; Patiar, S.; Winter, S.C.; Betts, G.; Homer, J.; Corbridge, R.; Cox, G.; West, C.M.; et al. hsa-mir-210 is a marker of tumor hypoxia and a prognostic factor in head and neck cancer. Cancer 2010, 116, 2148-2158. [CrossRef] [PubMed]

83. Ji, X.; Guo, H.; Yin, S.; Du, H. miR-139-5p functions as a tumor suppressor in cervical cancer by targeting TCF4 and inhibiting Wnt/ $\beta$-catenin signaling. Onco Targets Ther. 2019, 12, 7739-7748. [CrossRef]

84. Wang, K.; Jin, J.; Ma, T.; Zhai, H. MiR-139-5p inhibits the tumorigenesis and progression of oral squamous carcinoma cells by targeting HOXA9. J. Cell Mol. Med. 2017, 21,3730-3740. [CrossRef]

85. Rasmussen, C.L.; Sand, F.L.; Hoffmann Frederiksen, M.; Kaae Andersen, K.; Kjaer, S.K. Does HPV status influence survival after vulvar cancer? Int. J. Cancer 2018, 142, 1158-1165. [CrossRef] 
86. Zhang, J.; Zhang, Y.; Zhang, Z. Prevalence of human papillomavirus and its prognostic value in vulvar cancer: A systematic review and meta-analysis. PLoS ONE 2018, 13, e0204162. [CrossRef] [PubMed]

87. Hinten, F.; Molijn, A.; Eckhardt, L.; Massuger, L.F.A.G.; Quint, W.; Bult, P.; Bulten, J.; Melchers, W.J.G.; de Hullu, J.A. Vulvar cancer: Two pathways with different localization and prognosis. Gynecol. Oncol. 2018, 149, 310-317. [CrossRef]

88. Williams, A.; Syed, S.; Velangi, S.; Ganesan, R. New directions in vulvar cancer pathology. Curr. Oncol. Rep. 2019, 21, 88. [CrossRef]

89. Liu, X.; Cao, Y.; Zhang, Y.; Zhou, H.; Li, H. Regulatory effect of MiR103 on proliferation, EMT and invasion of oral squamous carcinoma cell through SALL4. Eur. Rev. Med. Pharmacol. Sci. 2019, 23, 9931-9938. [CrossRef] [PubMed]

90. Zhou, C.; Li, G.; Zhou, J.; Han, N.; Liu, Z.; Yin, J. MiR-107 activates ATR/Chk1 pathway and suppress cervical cancer invasion by targeting MCL1. PLoS ONE 2014, 9, e111860. [CrossRef] [PubMed]

91. Cui, F.; Li, X.; Zhu, X.; Huang, L.; Huang, Y.; Mao, C.; Yan, Q.; Zhu, J.; Zhao, W.; Shi, H. MiR-125b inhibits tumor growth and promotes apoptosis of cervical cancer cells by targeting phosphoinositide 3-kinase catalytic subunit delta. Cell Physiol. BioChem. 2012, 30, 1310-1318. [CrossRef]

92. Lu, H.J.; Jin, P.Y.; Tang, Y.; Fan, S.H.; Zhang, Z.F.; Wang, F.; Wu, D.M.; Lu, J.; Zheng, Y.L. MicroRNA-136 inhibits proliferation and promotes apoptosis and radiosensitivity of cervical carcinoma through the NF-кB pathway by targeting E2F1. Life Sci. 2018, 199, 167-178. [CrossRef] [PubMed]

93. Zhang, B.X.; Yu, T.; Yu, Z.; Yang, X.G. MicroRNA-148a regulates the MAPK/ERK signaling pathway and suppresses the development of esophagus squamous cell carcinoma via targeting MAP3K9. Eur. Rev. Med. Pharmacol. Sci. 2019, 23, 6497-6504. [CrossRef] [PubMed]

94. Jia, T.; Ren, Y.; Wang, F.; Zhao, R.; Qiao, B.; Xing, L.; Ou, L.; Guo, B. MiR-148a inhibits oral squamous cell carcinoma progression through ERK/MAPK pathway via targeting IGF-IR. BioSci. Rep. 2020, 40. [CrossRef] [PubMed]

95. Mou, Z.; Xu, X.; Dong, M.; Xu, J. MicroRNA-148b acts as a tumor suppressor in cervical cancer by inducing G1/S-phase cell cycle arrest and apoptosis in a caspase-3-dependent manner. Med. Sci. Monit. 2016, 22, 2809-2815. [CrossRef]

96. Zhang, H.; Lu, Y.; Wang, S.; Sheng, X.; Zhang, S. MicroRNA-152 acts as a tumor suppressor microRNA by inhibiting Krüppel-like factor 5 in human cervical cancer. Oncol. Res. 2019, 27, 335-340. [CrossRef]

97. Wang, X.; Li, G.H. MicroRNA-16 functions as a tumor-suppressor gene in oral squamous cell carcinoma by targeting AKT3 and BCL2L2. J. Cell Physiol. 2018, 233, 9447-9457. [CrossRef]

98. Wei, Q.; Li, Y.X.; Liu, M.; Li, X.; Tang, H. MiR-17-5p targets TP53INP1 and regulates cell proliferation and apoptosis of cervical cancer cells. IUBMB Life 2012, 64, 697-704. [CrossRef]

99. Koshizuka, K.; Hanazawa, T.; Kikkawa, N.; Arai, T.; Okato, A.; Kurozumi, A.; Kato, M.; Katada, K.; Okamoto, Y.; Seki, N. Regulation of ITGA3 by the anti-tumor miR-199 family inhibits cancer cell migration and invasion in head and neck cancer. Cancer Sci. 2017, 108, 1681-1692. [CrossRef]

100. Wei, D.; Shen, B.; Wang, W.; Zhou, Y.; Yang, X.; Lu, G.; Yang, J.; Shao, Y. MicroRNA-199a-5p functions as a tumor suppressor in oral squamous cell carcinoma via targeting the IKK $\beta / N F-\kappa B$ signaling pathway. Int. J. Mol. Med. 2019, 43, 1585-1596. [CrossRef]

101. Wei, D.; Wang, W.; Shen, B.; Zhou, Y.; Yang, X.; Lu, G.; Yang, J.; Shao, Y. MicroRNA-199a-5p suppresses migration and invasion in oral squamous cell carcinoma through inhibiting the EMT-related transcription factor SOX4. Int. J. Mol. Med. 2019, 44, 185-195. [CrossRef]

102. Qu, X.; Gao, D.; Ren, Q.; Jiang, X.; Bai, J.; Sheng, L. MiR-211 inhibits proliferation, invasion and migration of cervical cancer via targeting SPARC. Oncol. Lett. 2018, 16, 853-860. [CrossRef]

103. Zhu, L.; Tu, H.; Liang, Y.; Tang, D. MiR-218 produces anti-tumor effects on cervical cancer cells in vitro. World J. Surg. Oncol. 2018, 16, 204. [CrossRef] [PubMed]

104. Liu, C.; Zhang, Y.; Liang, S.; Ying, Y. Aldehyde dehydrogenase 1, a target of miR-222, is expressed at elevated levels in cervical cancer. Exp. Ther. Med. 2020, 19, 1673-1680. [CrossRef] [PubMed]

105. Chen, F.; Qi, S.; Zhang, X.; Wu, J.; Yang, X.; Wang, R. MiR-23a-3p suppresses cell proliferation in oral squamous cell carcinomas by targeting FGF2 and correlates with a better prognosis: miR-23a-3p inhibits OSCC growth by targeting FGF2. Pathol. Res. Pract. 2019, 215, 660-667. [CrossRef] [PubMed]

106. Xu, L.; Chen, Z.; Xue, F.; Chen, W.; Ma, R.; Cheng, S.; Cui, P. MicroRNA-24 inhibits growth, induces apoptosis, and reverses radioresistance in laryngeal squamous cell carcinoma by targeting X-linked inhibitor of apoptosis protein. Cancer Cell Int. 2015, 15, 61. [CrossRef] [PubMed]

107. Guo, Y.; Fu, W.; Chen, H.; Shang, C.; Zhong, M. MiR-24 functions as a tumor suppressor in Hep2 laryngeal carcinoma cells partly through down-regulation of the S100A8 protein. Oncol. Rep. 2012, 27, 1097-1103. [CrossRef]

108. Fang, F.; Huang, B.; Sun, S.; Xiao, M.; Guo, J.; Yi, X.; Cai, J.; Wang, Z. MiR-27a inhibits cervical adenocarcinoma progression by downregulating the TGF- $\beta$ RI signaling pathway. Cell Death Dis. 2018, 9, 395. [CrossRef]

109. Han, M.; Li, N.; Li, F.; Wang, H.; Ma, L. MiR-27b-3p exerts tumor suppressor effects in esophageal squamous cell carcinoma by targeting Nrf2. Hum. Cell 2020, 33, 641-651. [CrossRef]

110. Xie, R.; Wu, S.N.; Gao, C.C.; Yang, X.Z.; Wang, H.G.; Zhang, J.L.; Yan, W.; Ma, T.H. MicroRNA-30d inhibits the migration and invasion of human esophageal squamous cell carcinoma cells via the post-transcriptional regulation of enhancer of zeste homolog 2. Oncol. Rep. 2017, 37, 1682-1690. [CrossRef] 
111. Hu, J.; Gui, Y.; Xie, P.; Li, G. MicroRNA-33a regulates the invasion of cervical cancer cells via targeting Twist1. Zhong Nan Da Xue Xue Bao Yi Xue Ban 2015, 40, 1060-1067. [CrossRef]

112. Deng, Y.; Xiong, Y.; Liu, Y. MiR-376c inhibits cervical cancer cell proliferation and invasion by targeting BMI1. Int. J. Exp. Pathol. 2016, 97, 257-265. [CrossRef] [PubMed]

113. Shan, D.; Shang, Y.; Hu, T. MicroRNA-411 inhibits cervical cancer progression by directly targeting STAT3. Oncol. Res. 2019, 27, 349-358. [CrossRef] [PubMed]

114. Xin, J.X.; Yue, Z.; Zhang, S.; Jiang, Z.H.; Wang, P.Y.; Li, Y.J.; Pang, M.; Xie, S.Y. MiR-99 inhibits cervical carcinoma cell proliferation by targeting TRIB2. Oncol. Lett. 2013, 6, 1025-1030. [CrossRef] [PubMed]

115. Wu, T.; Chen, X.; Peng, R.; Liu, H.; Yin, P.; Peng, H.; Zhou, Y.; Sun, Y.; Wen, L.; Yi, H.; et al. Let-7a suppresses cell proliferation via the TGF- $\beta /$ SMAD signaling pathway in cervical cancer. Oncol. Rep. 2016, 36, 3275-3282. [CrossRef]

116. Guo, M.; Zhao, X.; Yuan, X.; Jiang, J.; Li, P. MiR-let-7a inhibits cell proliferation, migration, and invasion by down-regulating PKM2 in cervical cancer. Oncotarget 2017, 8, 28226-28236. [CrossRef]

117. Zheng, S.; Liu, Q.; Ma, R.; Tan, D.; Shen, T.; Zhang, X.; Lu, X. Let-7b-5p inhibits proliferation and motility in squamous cell carcinoma cells through negative modulation of KIAA1377. Cell Biol. Int. 2019, 43, 634-641. [CrossRef] [PubMed]

118. Hou, B.; Ishinaga, H.; Midorikawa, K.; Nakamura, S.; Hiraku, Y.; Oikawa, S.; Ma, N.; Takeuchi, K.; Murata, M. Let-7c inhibits migration and epithelial-mesenchymal transition in head and neck squamous cell carcinoma by targeting IGF1R and HMGA2. Oncotarget 2018, 9, 8927-8940. [CrossRef]

119. Zheng, Y.; Luo, M.; Lü, M.; Zhou, T.; Liu, F.; Guo, X.; Zhang, J.; Kang, M. Let-7c-5p inhibits cell proliferation and migration and promotes apoptosis via the CTHRC1/AKT/ERK pathway in esophageal squamous cell carcinoma. Onco Targets Ther. 2020, 13, 11193-11209. [CrossRef]

120. Wang, S.; Jin, S.; Liu, M.D.; Pang, P.; Wu, H.; Qi, Z.Z.; Liu, F.Y.; Sun, C.F. hsa-let-7e-5p inhibits the proliferation and metastasis of head and neck squamous cell carcinoma cells by targeting chemokine receptor 7. J. Cancer 2019, 10, 1941-1948. [CrossRef]

121. Cheng, Y.; Guo, Y.; Zhang, Y.; You, K.; Li, Z.; Geng, L. MicroRNA-106b is involved in transforming growth factor $\beta 1$-induced cell migration by targeting disabled homolog 2 in cervical carcinoma. J. Exp. Clin. Cancer Res. 2016, 35, 11. [CrossRef]

122. Wang, M.; Wang, X.; Liu, W. MicroRNA-130a-3p promotes the proliferation and inhibits the apoptosis of cervical cancer cells via negative regulation of RUNX3. Mol. Med. Rep. 2020, 22, 2990-3000. [CrossRef] [PubMed]

123. Li, J.H.; Zhang, Z.; Du, M.Z.; Guan, Y.C.; Yao, J.N.; Yu, H.Y.; Wang, B.J.; Wang, X.L.; Wu, S.L.; Li, Z. MicroRNA-141-3p fosters the growth, invasion, and tumorigenesis of cervical cancer cells by targeting FOXA2. Arch. BioChem. Biophys. 2018, 657, 23-30. [CrossRef] [PubMed]

124. Wang, H.; Hu, H.; Luo, Z.; Liu, S.; Wu, W.; Zhu, M.; Wang, J.; Liu, Y.; Lu, Z. MiR-4454 up-regulated by HPV16 E6/E7 promotes invasion and migration by targeting ABHD2/NUDT21 in cervical cancer. BioSci. Rep. 2020, 40. [CrossRef] [PubMed] 